\title{
Monasticism from the Point of View of Christianity
}

Yaldā Bābāyi

PhD Student in Islamic Gnosticism, Azad University (Najafabad Branch) - Ministry of Education, District 2 of Isfahan

Ali-Rezā Fahim

Shahr-e-Kord University, Faculty of Literature and Humanities, Department of Religions and Comparative Gnosticism

Monireh Mosayebi

MA in Persian Literature, Ministry of Education, District 2 of Isfahan

Mehri Āghāsi

MA in the History of Islamic Culture and Civilization, Ministry of Education, District 2 of Isfahan

\section{Doi:10.5901/mjss.2015.v6n6s4p383}

\section{Abstract}

Monasticism, which means fear and awe, has an Arabic root. There are many definitions for this word. Forgetting about the world, the people, permanent celibacy, and retreating into oneself for the sake of worshipping are common features among these definitions. Monasticism was born in the third century AD among the Christians. During that time, some people turned away from religion and spiritual teachings and turned into monasticism. Against this group, there were a group of people, who turned their back at the world and turned into worshipping, spirituality, and religion. They took refuge in the monasteries. Using an analytic library research method, this research deals with monasticism movement and investigates it in different sects of Christianity in order to emphasize the point that monasticism does not have a root in Christianity and has been created by a group after Christianity. The founder of monasticism is a person named Antonios from Egypt whose way and teachings was followed by many people later.

Keywords: Monasticism, Monastery, Sect, Christianity, Quran

\section{Introduction}

\subsection{The origin of monasticism}

Monasticism was born in the third century AD among the Christians. The Christian monks turned away from the mundane materials and came together in the monasteries. Monasticism developed little by little and found many fans and supporters. Some people found the cause of the others' tendency to monasticism in the point that while some get away from religious teachings and turn into luxury, some others turn into spirituality and get away from the world and mundane materials. Among the other reasons of the tendency to follow monasticism was the oppression and tyranny on the part of the rulers who made people dissociable due to their harassment so that these people took refuge in the mountains and caves. During the medieval in Europe, there were many mystics as the natural fruit of a bright monastic period of life. Two normal and standard backgrounds were required for mysticism. The first was based on asceticism, which let everyone overcome the physical and sensual attraction found in everything. The second was a life dedicated to meditation and refinement, which opens the way for a person to his/her inner voice of conscience and both of whom could be simply done by monks in order to make people try their best for meeting their materials and basic needs such as food, clothing, and family. Like eastern tradition, monasticism is usually considered as the best and the most valuable kind of Christian life since it was only in this kind of behavior that everyone was permitted to concentrate on God and the related religious matters.

From the beginning in the Occident, for more than 800 years, mysticism had a monastic aspect and originated from the asceticism of the people in the deserts (EstivenFaning, 2005). Three people of founders of the western mysticism 
were the monks. The first was YuansKasyanus who lived in the deserts of Egypt, turned back to west as a monk after finishing his discipline period and organizational rules, and built a convent for the monks in Fear French (the same).

In this article, we try to investigate monasticism from the perspective of Christianity and the differences between Islam and Christianity about this issue.

\subsection{The significance and necessity for this research}

Recognizing the mysticism of Christianity, which comes from the biggest revelation religions in the world, is very essential in the current world. It must be particularly mentioned that this issue has been neglected in Persian works.

From a long time ago, many Christians tried their best to recognize the Islamic mysticism. If Reynold A. Nicholson from England has studied and researched for many years in the works of Molana Rumi and Attar and has written one of the richest descriptions on Masnavi, he must be definitely looking for a fact, which we can also find in the works of Alhart and Francis Assizi in another way. This paper, using an analytical research method, and through investigating different books and documents tries to find the facts about monasticism in different sects of Christianity to uncover the truth about the origin and developments of this trend in Christianity.

\section{The Lexical Root of Monasticism}

In order to investigate the monasticism and its path of change throughout history, first we need to investigate this word from a lexical perspective. "Monasticism" is an Arabic word and most Arabic lexicographers often put this word as equivalence for "monastic" which means fear and awe. Khalil Farahidi mentions a point here: "I was scared of something and made it scared, how scary it is" (Farahidi, 1409, volume 40, p. 477).

Some lexicographers emphasize the point that the plural form of the word "Raheb" in Arabic is "Rahban" not "Rahbaniat" (EbnManzoor, 1405, volume1, p. 436).

In this regard, Abu Halal Asgari investigates the differences between "Kho'f" and "Rahab" in Arabic and this is because of this that "Raheb" is called "Rahebeh" since he is continuing the "Kho'f" (Asgari, 1991, p. 261).

According to the scholars of lexicon, "Tarahob" means "worshipping" in the monastery and "Raheb" which is taken from the root "Rohbaniat" and "Raheb" is a person who is worshipping in a monastery.

RaghebEsfahani also knows "Rahbaniat" from the root of "Rohb" meaning fear with anxiety.

According to him, "Tarahob" means worshipping and "Rohbaniat" is indulgence in tolerating this worshipping due to a high degree of fear and against the other lexicographers, he knows "Rohbaniat" as the best plural form for the word "Raheb". (RaghebEsfahani, 1990, p. 204).

In a similar text from AllamehTabatabaie: "Rohbaniat comes from Rohb which means fear and conventionally means separating from people for worshipping God due to the fear of him." (Tabatabaie, 1996, p. 180).

The word "Raheb" comes from the root "Rohb" which means fear and refers to a person who is afraid of God and starts worshipping Him. The Persian equivalence for this word is "Tarsa" which expanded many years later and was told to the Christians (Mosaheb, 1345, p.36).

In explaining the difference in opinions between the lexical root of "Rohbaniat" about the question that is this word plural or singular, we can refer to the book "Mo'jamolvasit" which is one of the most valid Arabic books. In this book, the root of "Rohbaniat" is said in this way: "Rahab-Rahaban: Khaf, Alrohbaniat: Tarigholrohban." (Ma'loof, 1995, p. 282).

Permanent celibacy and taking shelter in the mountains and jungles and breaking the relationships with people for the sake of retreating due to worshipping is one of the features used for monasticism (Mavardi, 1981, volume 5, p. 484).

Among the Christians, monasticism is retreating from the world and everyday life activities due to worshipping and other religious reasons (ZibaieNezhad, 1996, p. 95).

Leaving the people, retreating, forgetting the mundane activities, and doing the religious activities are among the common issues, which involve these definitions. Finally, we can conclude that the word "monasticism" is a singular word and is the method of monks.

\section{Who is a Christian Monk?}

A person who starts retreating and forgetting the mundane activities is called a monk. He has particular characteristics, which many authors have mentioned.

A monk escapes from the society, commitment, and social duties, considers them as a mundane and trivial thing, takes shelter in the monasteries, and looks at health, cleanliness, strength, choosing a spouse, and bringing a child into 
this world with contempt. The world, which the monk leaves, is the world of work, activity, commitment, and social duties. In a monk's view, this world and the world hereafter are two completely separate worlds and are not in relationship with each other (Motahari, 1999, p. 221).

What is inferred from these studies is that the life of most of the monks in the fourth century AD was mostly spent on manual work and besides that worshipping and benediction. Usually, while they were working on the farms or they were preparing clothes or food, they sang songs or verses or started saying different parts of the Bible by heart. All the residents of the monastery used to get together two or three times in a day usually in the early morning or at nights in order to read or listen to the Bible. The monks used to live in poverty. Many of them used to sell their food, clothes, or other products. However, they usually spent this money on buying the requirements for monasteries or helping the poor in the farms or other surroundingvillages (Nardoo, 2006, p.88).

The Christian monks, who were considered as the missionaries of the church in the Medieval, could be the factor of attracting those who escape from Christianity due to the negative performance of the secularists' church. Besides this, the dark monasteries of 500 or $1000 \mathrm{AD}$, i.e. when the civilization and urban life collapsed due to the dominance of the Roman Empire, tried their best for keeping knowledge. They founded elementary schools in monasteries and started duplicating from the texts. The monks, especially the British ones, were the annunciators of the church in the Medieval and some of the most important leaders of the church such as (the seventh Grigoor" rose from the monasteries (Corner, 2008, p. 125).

One of the most obvious examples of monasticism in the Medieval is "the Begins". They were a group of nuns who appeared in the twelfth century $A D$ and they did not have any commitments except an ascetic life and chastity (Faning, $p$. 191). Marie of Oignies, Liutgard, and Christina (1737-1809) were some members of this group.

\section{The First Monk}

Many authors have written about the question that who started monasticism and who founded the principles of this method of living. Many have agreed upon the fact that AntoniGhedis was the first one who stepped on this way. He was from Egypt who lost his land, spent most of his long life, which was about 1.5 years, in deserts with poverty and worshipped, fast, and resist against Satan. His way of life strangely influenced the Christians in Egypt, many people went to the deserts for visiting him, and many left the world and shared his asceticism. These biased monks tolerated the dry and warm weather of the desert and were able to stand many difficulties (Miller, 12962, p. 259).

Corner also agreed with Miller. He also introduces Antoni as the first monk and says: "The founder of monasticism is usually known as a person called Antoni (865-966). He sold all his properties when he was 20 years old and gave the money to the poor and went to a remote cave and spent his life contemplating. He was so of holiness fame that many people went there and became residents near him in the surrounding caves (Corner, 2008, p. 124). A person named GhedisAntonios was from Egypt. After following monasticism as his way of life, he finally went to deserts and started a life of retreating and celibacy (Corner, 1991, p. 639).

In the book "The religious world", AntoniGhedis,from Egypt, is the first Christian monk. Most of the people believe that monasticism in Christianity started in Egypt with Antoni (who passed away in 966 AD): "Antoni who dedicated his life to asceticism and retreating, is a person who gave all he had to his people and started living in deserts lonely. He attracted many fans and in the beginning of the fourth century AD organized a group of monks in order to live in a simple place under a system and religious regulations." (Boosh, 19954, p. 753).

Some authors disagree with the theory that Antoni is the first figure in monasticism. According to him, the first monk is "YouhanaKasyans" and he considers Bandiket" as the authentic father of monasticism. According to him, the first person who wrote about the monastic life is "YouhanaKasyans" (435 AD) and the authentic father of monasticism in west is Bandiket (Mobarak) (457 AD). He decided his life to solitude and worshipping in the mountains near Rome when he was young and during several years, some people went there first for worshipping and then for living with him. Badiket regulated a rule for group life, whichwas consideredas the most important document in monasticism history in west later (Michele, 2002, p. 144).

Binas believes that: "a leader named Bazil who was the first bishop of the Caesarea (and is still famous for his retreating in Ortodox church of the East) paid attention to them and regulated rules for them which are still common among the Ortodox Christians. In this way, the monasteries were under the penetration and power of the bishops and it followed the traditions of the west countries. They also considered drinking wine and reading non-religious texts unlawful; they spent their time providing social services and helping the poor and orphans" (Binas, 1991, p.640).

However, Lucas had an opinion in contrast with that of the others. He considers monasticism rule as "GhedisPakhoomious": "GhedisPakhoomious regulated a general rule for religious life. According to his rule, each monk 
has his own single chamber. However, working, praying, and reading religious texts were in a choir. Many people accepted Pakhoomious rule. Soon after that thousands of people started following Pakhoomious rule in Egypt". (Lucas, 1987, p. 301).

\section{Monasticism in the Sects of Christianity}

Monasticism is divided into two parts in Catholicism: The individual part and the collective one. According to many authors, the founder of individual monasticism is a person named Ghedis Antonious from Egypt. He dedicated his life to retreating and solitude. He granted all his properties and started living in deserts by himself. Although for Antonious, monasticism was individual, many others, like him, followed such method. Meanwhile, his monasticism was known as "Hermit" or "Ermitik". History talks about strange events in the life of such monks. For example, a monk named Markarious did not eat meat for seven years, did not sleep for twenty years, and slept for 6 months while he was naked in the exposure of the poisonous bites of the mosquitoes in a swap. Other monks used to carry heavy loads on their shoulders or fasten their hands and feet with shackles wherever they wanted to go." (Dorant, 1371, p. 74-75).

First, the monks used to live by themselves. However, little by little, they formed a group and went under the leadership of a great monk. There was a huge difference between this group and the individual life since this group not only provided the opportunity for self-purification and praying, but also provided an opportunity for education and services to humanity. The founder of collective monasticism according to some historians is a person named "GhedisPakhoomious" who paved the way for founding monasteries for the monks.

"Pakhoomious" considered individual retreating as a sign of egoism and founded the collective monasticism in Egypt in 325 AD. His monasticism was known as "Senoobitik." (Boosh, 1995, p. 753).

ZibayieNezhad also agreed with Boosh and knew Pakhoomious (Pakoomious) the first monk who tended to collective monasticism. According to him, the start of this method was in $325 \mathrm{AD}$ when this monk realized that retreating is a sign of egotism and he gathered some devout people in Egypt and founded the collective monasticism (ZibayieNezhad, 1996, p. 96). When the monks got together, they started working in agriculture, building boats, and things like that while they were doing their religious affairs. In this way, they were able to earn money and help the poor as well. This was the beginning of the huge movement in the fourth century AD.

From that time, many people other than the formal staff of the church, started retreating till in the late 6the century $A D$, monasticism penetrated into both eastern and western parts of the church: "this movement is still of a significant position in Catholic church." (ZibayieNezhad, 1996, p. 96).

Orthodox Christianity, like Catholic, is still witnessing the creation of monastic sects. The Christian researchers believe that monasteries in AtoosMountains in a peninsula in the North of Greece and a monastery called KatrinayGhediseh in Sina mountain play significant roles in monasticism in Orthodox Church.

The base of work of the Orthodox monks was the regulations of Basil. Orthodox monasticism is in close relationship with the doctrine of "Heziklasm". This word is of a Greek root and means peace. It is said that this method was created in the fourth and fifth $A D$ century among the monks of Anatoli and Greece. The most outstanding theorists of that doctrine are ShamoonNoorolahi (1022 AD) and Grigoori Palmas (1359) who built what was common among the monks of Aloos and Sina mountains during centuries. This wave of monasticism first appeared in Russia and was considered as the sign of spirituality and monasticism: "the monks of this doctrine read a mention named Jesus mention which is constantly repeated and the two eyes concentrate on the heart at the same time and their physical force such as the senses and the mind are closed." (Boosh, 1995, p. 755). Monasticism in the evangelical sect was like the Catholic sect. however, in the $16^{\text {th }} A D$ century, the monasticism system put this sect away and formed its own population.

In the $16^{\text {th }}$ century, evangelicals put away the monasticism system of the Rome Catholic and instead formed populations consisting of men and women in some churches. This population was named the population of brothers and sisters who were similar to the monks of Catholic Church. The evangelical Christians do not tend to mysticism and monasticism since they do not find clear evidence for this in the Bible and the experience of the initial church. However, monastic sects in evangelicals also appeared. Some of these sects are point at in the following:

1. Ramshyan: The founder of this sect was JakoobBoomeh( 1624AD) from Lootery church. He believed that whatever he writes \& mentions originates from the divine light, which is inspired on him. The followers of this group prevent anyone from making effort and believe that it is obligatory for a faithful person to wait and let God decide and act for him: "some of the people of this group formed "friend's community" who were formed as "Fernedz" or "Kuikerz". This group lacked clear rules as well as a single leader and believed that God will choose whomever he wants for talking with the group. They also emphasized on inward light which meant the feeling of the God's existence and the direct act of Christ in human life (Boosh, 1995, p 754). 
2. Parsayan: The origin of this doctrine was a reform movement which appeared in $17^{\text {th }}$ century in Looteri church of Germany and it was the reason of paying particular attention to wisdom and being remote from a dynamic and active faith.

3. Methodism: This sect appeared in England with the leadership of John Vezli (1788 AD). The movement of this sect was like Parsayan.

4. Pentykalysm:This sect grew in the $19^{\text {th }} A D$ century in the movement- oriented environments of America. The members of this doctrine emphasize on "baptism in holy spirit" baptism versus with water: "In order to prove the role of Holy Spirit in the world, they attached high significance to fantastic gifts which are mentioned about the initial societyof Christianity or in Pools dissertations. The slogans of this group were so simple, natural, and with piety "(Michel, 2002, p. 150-151).

\section{Does Monasticism Have a Proper Root in Christianity?}

The present Christianity is mixed with monasticism and its strict rules have been reduced over the recent period and have been combined with hierarchy of social services; however Quran believes that monasticism is one issue which has been mixed with Christianity later and this is mentioned with the sentence " we did not order in such a way". Its individual and society harms are so obvious that evangelical,a group of intellectuals who follow Christianity induce celibacy, which is the base of monasticism, andlet the priests and padre get married.

Dorant believes that in addition to rational evidence and the past calculations, the historical documents provide evidence that the next group has made monasticism, Christianity does not know about it, and social services, education, close not have any relationship with building monasticism, celibacy, and forgetting about marriage. He believes that social services that the monks started after building the monasteries is not related to monasticism. They know the reason of it in this case; since services and helping the society, especially the sick is also possible without celibacy and retreating from this mundane world. There is no need to bewith monasticism, there are many people who did big services while they were enjoying the permissible pleasures of life (Dorant, 1992, volume 11, p. 405).

If Jesus lived in simplicity and retreating and forgot about everything, it was because he wanted to show a desirable image of his divine goal of fighting by both words and actions and also his apostles were asked to follow his way for the sake of following Jesus goal. He never asked them not to get married or start living in monasticism, retreating, and fasting or spend all their life in the corner of monasteries in deserts. Quran has mentioned in this way: "then we sent prophets after Noah and Abraham and then we sent Jesus and gave him Gospel and we put kindness and compassion in the heart of his followers but they replaced it with monasticism as an innovation and we did not ask them to do so. We asked them to look for God's satisfaction but they did not observe our rules and regulations.

According to Tabresi, the creation of monasticism was because of gaining God's satisfaction. Regarding the sentence (ifyou want God's satisfaction 2-3/65), he concludes that the idea of the monasticism's founders was firstly to gain God's satisfaction. Since monasticism was actually a kind of belief or promise with God in which the monk wants to dedicate his body and soul to worshipping, but later he does not keep his promise and disobeysmany of its conditions.For more explanation, he narrates from EbneMasood from the holy prophet: one day after the Christ, the rulers dominated on people, there was a war between them and the faithful people,and lots of them were killed. The minority of them felt that if they resist more versus them, they will be all killed and therefore Christianity will be extinct. In order to prevent this extinction, they took shelter in the caves and waited for a prophet whose name Christ (Tasrei, 1993, volume 9, p. 243) promised. The narration, which Ebne Masood mentions from the prophet, is the base of their work. They left their home for following God's way and went into the mountains and caves.

\section{How was a Monastery Created?}

After the Antonios way became common among people, the monks decided to live in groups. Antonios way spread in Egypt because of its atmosphere and social conditions and found its own fans. After a short period, it became famous that loneliness and sole retreating make people madness and insanity. In this regard, in the society of Copic Christians, the method of group retreating and common life of monks appeared. Binas regards the group life of the monks as the cause of building monasteries in the south of Egypt: "there, a group of ascetics started a regular life under the leadership of the elders whodivided the time for retreating, worshipping, working, and caring fairly. This method went out of Egypt and was current in Damascus and Minor Asia." (Binas, 1991, p. 639).

One of the factors, which led to creating monasteries, was that Ghedis Basil did not consider retreating practical. Therefore, he gathered a group of religious men in order to live in a complex. According to the rule he prescribed, he 
used to spend his life worshipping, contemplating, studying, and manual work. In this regard, the first monasteries were created. Lucas considers this action a development: "since if the individualist wasteful monks did not create institutions for education, they would never be able to leave the civilization effect on the regular monasteries in the middle age."

Monasticism had particular architecture. The monasteries were buildings consisted of a chapel and a place for eating food, which was under a single ceiling in the upper part of that there was a chapel, which attached to the down part by a ladder. "The sleeping place for each person was a wooden box whose floor was soil. The food of the monks was exclusively plant, sometimes they used fish, and there was not any wheat or spice in their food (Dorant).

Each monastery had a manager who had particular duties some of the managers gained high reputation.In the center of each monastery, they chose a manager for four years. However, the problems started when the managers became the officers for inquisition and first they did not want to do so. When they turned into their main tendency, they found reputation among special classes. Great authors and teachers who were perfect in theology raised during this time. The monasteries played significant roles in keeping and recording different sciences and also in expanding knowledge since the monks were acquiring and recording knowledge there. This has been mentioned in the book "the story of Christianity" throughout history". In this way: "the monasteries contributed a lot in keeping the knowledge during the medieval between the years 500 to $1000 \mathrm{AD}$. This was the time when the civilization and urban life was collapsing due to the domination of Barbarians on the Rome Empire. Those people who were fond of learning could have their elementary education in the schools of monasteries." (Corner, 2008, p. 126).

The monastery and the monks played a significant role in keeping the Bible by memorizing this book; they led the wild people in Europe and Asia. Miller considers the monasteries as the firm castles of the church and the center of knowledge, awareness, asceticism, and piety. If the monks did not try in keeping the knowledge and science, they would completely eradicate and disappear. The monks read the Bible carefully and guided the wild people in Europe and Asia to the Christ way. The most important monastic center was a monastery built in 963 AD in the peninsula "Atoos". This center developed little by little and became like a monastic society. During the past centuries, monasticism declined and many people forgot about living in monasteries. Atoos peninsula is now called "magnificent ruins". Orthodox Church in its west meaning does not have any regulations about monasticism. Each monastery is a single unit, which is under the legal authority of a local bishop: "in orthodox, monastery is in its collective form in a retreating way. The monasteries are not in high levels from the perspective of cultural system (Mooland, 1989, p. 46).

\section{Monasticism from Quran Perspective}

According to Islam, Christian monasticism is rejected. God has mentioned the monasticism issue in some verses.

- Then we sent our prophets after that and we sent Jesus, son of Mary, we granted Gospel to him, we endowed kindness in the hearts of those who follow them, and we did not order monasticism, which they excogitate. Although they aimed at God's satisfaction, they did not have respect for the right. In this regard, we rewarded those who believe in God and many of them had debauchery behaviors. According to this respectful verse, monasticism was not something existed in Moses' teachings. However, some Christians invented such a method by themselves. Holy Quran clearly points out that they intended to gain God's satisfaction at first but then they did not insist on their intention and they did not enounce the right. In another verse, Quran makes it clear that some Christians absolutely obeyed the scientists and monks:

- There are idols against God and (also) against Christ, the son of Mary. People are ordered to worship the unique God because except Him there is no other God. He is far away from what people describe and what they consider as His peers (31/Tobe). God does not accept excess in worshipping or not doing it at all but God wants people to keep the balance in order to step in the right way and provide their luggage futurity in this world. Islam stands in stark contrast with monasticism as the means of remoteness from the sins and discharging the heart from mundane activities and use it in order to approach God.

- Investigation and conclusion:

\section{Conclusion}

It can be concluded that monasticism is retreating and forgetting about the social activities, paying attention to religious matters, and devoting oneself to God. According to some, human being is guilty and needs punishment. Some Christians start retreating from the first in order to repress themselves and approach God. They believe that it was not possible to make their foul soul good and human being should choose solitude in order to gain perfection. Monasticism movement, according to historians, was born after the Christ since he never ordered to forget about marriage and social activities. 
The goal of a monk is gaining God's satisfaction. A monk actually has a promise with God and dedicates his soul and body to his promise. What is obvious is that God has always invited human beings to keep the balance in everything. Human approach to God is not impossible with social and family life. It can also be a factor for improving human faith and spirituality.

\section{References}

Amid-Zanjani, A. A. (1967). Tasav of history. Tehran: Eslamieh Publications.

Asgari, A. H. (1991). The roots of words. Tehran: Bija Publications.

Binas, J. (2002). The history of religions. Tehran: Bija Publications.

Boosh, R. (1995). The religious world. Translated by: Dr. AbdolrahimGhavahi, Tehran: The office of publication and Islamic culture.

Corner, Oral, (2008). The history of Christianity throughout history. Translated by: Arman Roshdi, llam.

Dorant, Will, (1992). The history of civilization. Tehran: Eghbal.

EbneManzoor, Ela FarighiMesri, Mohammad, (1984), Sanolarab. Beiroot: Darolsader.

EstivanFaning, (2005), Christian mystics, translated by: FaridodinRadmehr, Tehran, Nillofar.

Farahidi, Khali ebne Ahmad, (1998), alien, Ghom.

Hium, Robert Ernest, (1994). The living religions of the world. Translated by: Abdol Rahim Govahi, Tehran: science.

Hoop, Jin, (1999), Buddha. Translated by: Ali Kashefi pour, Tehran: Shirazeh.

Lucas, Henry, (1987), civilization history from the oldest time till our decade. Translated by: Abdol Hossein Azarang, Tehran, Keihan.

MakaremShirazi, Naser, (1966). Nemooneh interpretation. Ghom.

Maloof, Luis, (1995), Almonjad fi Loghat: Tehran: Franklin.

Masaheb, Gholam Hossein, (1966), Persian cyclopedia. Tehran: Franklin.

Mavardi, Abolhasan, Ali ebne Mohammad, (1981), Alnokat and Oyoon interpretation. Tehran.

Micheal, Toomas, (2002), Christian speech, translated by: Hossein Tofighi, Ghom: studying and researching center of religions.

Miller, William, (2003), the history of ancient church in Rome and Iran Empire, translated by: Ali Nokhostin, Tehran, Negar.

Mooland, Inar, (1998), Christianity world. Translated by: Mohammad Bagher Ansari and MasihMohajerani, Tehran: Amir Kabir.

Nardo, Run, (2006), the creation of Christianity, translated by: Mahdi Haghighatkhah, Tehran, Ghoghnoos.

RaghebEsfahani, Abolfaraj, (1990). Almofradat in Gharib Quran.

Tabatabaie, Mohammad Hossein, (1996). Almizan interpretation. Tehran.

Tabresi, Fazlebne Hassan, (1993). Majmaolbayan in Quran interpretation. Tehran: Naser Khosro.

ZibaieNezhad, Mohammad Reza, (1996), an introduction to the history and speech of the Christianity. Ghom: Eshragh. 